\title{
Watson to take the helm at Soros institute
}

Moscow. Nobel laureate James Watson is to take over from Harley Balzer as chairman of the executive committee of the International Science Foundation (ISF), the body set up by Hungarian financier George Soros to provide financial assistance to scientists in the former Soviet Union (FSU).

One of Watson's first tasks will be to secure new funding for the foundation, following Soros's decision that he will only provide further funds (in addition to the $\$ 100$ million he has already donated) where these match money raised from elsewhere.

In the short term, the ISF is still hoping to receive a grant from the US State Department sufficient to keep its grants programme running when Soros's money runs out. The longer term remains uncertain, since the US government has indicated its reluctance to spend large amounts of money in support of scientists in other countries.

As a result, Watson is said to be already engaged in a search for alternative donors, although one option is to try to persuade influential Congressmen to put pressure on the State Department to increase its commitment.

One issue concerning the foundation is the shortage of current scientific journals in FSU states, a situation which makes it virtually impossible for scientists to carry out effective research. The ISF has agreed to provide $\$ 4$ million to address this problem, and a first shipment of journals is due to arrive in Russia in the near future, to be distributed to the leading libraries.

Another scheme supported by the foundation is a $\$ 5.5$ million project to keep scientists in FSU states in touch with those elsewhere through satellite communications. Telecommunications systems connecting Moscow to Stockholm and Washington are currently being installed to reduce the cost of electronic mail for Russian scientists.

ISF's travel grant programme has already proved successful. The foundation has sent about 1,500 FSU scientists to foreign conferences, at a cost of $\$ 2$ million. Its executive committee has now decided to extend this programme and has allocated a further $\$ 5$ million to it.

Meanwhile several other programmes aimed at supporting science in Russia some drawing directly on the ISF's expertise - are soon to start operation. These include the Howard Hughes Medical Institute, which plans to award 100 research grants worth $\$ 100,000$ each. Fifty will be awarded for biomedical research carried out entirely in FSU states, and the remaining 50 for collaborative research projects with US scientists.

Germany's Volkswagen Foundation has also announced plans to support joint Russian-German research projects, with individual grants also of $\$ 100,000$. In a separate

initiative, the Dutch government has launched a scheme for financing research involving Dutch and Russian scientists. The British government has already had such a scheme in place for some time.

Apart from the ISF, however, the largest source of financial support is the fund set up by the European Community (EC). Originally known as the Mitterrand Foundation, as it was created at the suggestion of the French president, 홍 this has now been renamed INTAL (an abbreviation for UNAVAILABLE the International FOR COPYRIGHT REASONS Promotion of Cooperation with Scientists from the Newly Independent States of the FSU).

The association James Watson: seeking has been given new funding.

21 million ECUs (US\$23 million) up to the end of this year to support joint projects involving scientists from FSU states and those from at least two European countries (purely bilateral collaboration is being handled at a national level).

\section{China counts the cost of higher education}

Beijing. As a new academic year opens, complaints are running high in China over the costs of university education. In the past, the government paid for everything, from tuition to accommodation, and guaranteed every student a job on graduation. But neither practice remains in force.

The State Education Commission has introduced a series of reforms to the country's higher educational system. Each university can now charge students for tuition, a move intended to ease the financial burden of the central government.

But as a result of these reforms, an increasing number of students are having to finance their own university education. According to the Shanghai Educational Test and Enrolment Center, over 6,100 self-supported students will be enrolled in Shanghai alone this year, just under 40 per cent of the total study enrolment.

Tuition fees vary. In Shanghai, selffinanced students in liberal arts are being required to pay 2,500 yuan for one academic year, engineering students 2,700 yuan and arts students 3,000 yuan. The figures in Beijing are much larger, with an average annual tuition cost of about 4,000 yuan.

Such costs are high for many ordinary Chinese families. In a country where higher education can be the only path to a successful career, every means is being explored to
A deadline of 15 October had originally been set for the receipt of declarations of intent for all this money. But after concern had been expressed about the time needed for information about the programme to be disseminated - particularly to researchers working far from Moscow - the schedule has been revised. As a result, applications for half of the money still have to be submitted by the original deadline. But the executive committee of the association has agreed to set a second deadline at the end of January for the rest.

Meeting at the end of September, the association also agreed to accept two nonEC countries, namely Austria and Switzerland, as members. No budget has yet been set for next year, although officials say that the European Parliament will agree to a figure that is at least as high as this year's.

Vladimir Pokrovsky

In a recent article on President Yeltsin's decision to increase the stipends paid to members of the Russian Academy of Sciences (see Nature 365, 379; 1993), it was stated that the value of the new stipend of 150,000 roubles a month was worth the equivalent of US $\$ 1,100$. This figure should have been $\$ 110$.

secure the money needed. But many students from rural or frontier regions cannot afford to pay the high fees for their university education, and as a result the door of higher education seems closed to them.

This situation has prompted the State Education Commission to take action. In a circular issued jointly with the Ministry of Finance, it has asked universities to help students in particular need, for example by reducing tuition fees and granting of loans.

Some universities have already come up with their own strategies to cope with the challenge. For example, Southeast University located in Nanjing, the capital city of South China's Jiangsu Province, has introduced three ways of treating newly enrolled students, based on academic performance.

Those students in Category A, judged by their scores on a national college entrance examination, will receive full scholarships covering tuition and living. Students in category $B$ will have tuition fees paid, but have to pay living expenses. Category $\mathrm{C}$ students cover their education entirely on their own.

These three categories will be rearranged each term according to the students' performance. But critics still argue that additional action needs to be taken to ensure that students from poorer families are not disadvantaged by being judged purely on their academic achievements.

You Qin LI 